\title{
EKSPLORASI BAKTERI ENDOFITIK DAN POTENSINYA DALAM PENGHAMBATAN JAMUR AKAR PUTIH (RIGIDOPORUS MICROPORUS)
}

\author{
Exploration of Endophytic Bacteria and Its Potency to Inhibit White Root Fungi \\ (Rigidoporus microporus)
}

Budi SETYAWAN", Intan BERLIAN dan Nur Eko PRASETYO

Balai Penelitian Getas, Pusat Penelitian Karet

Jalan Pattimura KM 6 Salatiga Jawa Tengah

Email: bud1se@yahoo.com

Diterima : 4 Agustus 2016 / Direvisi : 26 September 2016 / Disetujui : 25 Oktober 2016

\begin{abstract}
One of the control measures of white root disease which is promising to be developed in the future is biological control using microbial antagonists. Endophytic bacteria have been used to inhibit the growth of pathogens. Objective of this study were to explore and identify the endophytic bacteria from rubber and reveal its potency against $\mathrm{R}$. microporus. Five bacterial strains with initial inhibition zone were isolated from endemic (strain A10, A14, A16) and non-endemic (strain GN1, GN2) areas of white root disease. Direct opposition test showed that isolate A10 has widest inhibition zone $(0.3 \mathrm{~cm})$ on 4 days after inoculation among isolates. Molecular identification based on 16S rRNA and gyrB gene sequences revealed that the selected isolate A10 belongs to the Bacillus cereus group. Protease enzyme activity on skim milk medium and the ability of gelatine liquefaction were demonstrated by B. cereus A10. Bacterial extracellular filtrate tested with paper disk method indicated a non-consistent inhibition zones on each concentration, there were no significant difference between treatments on 3 DAI. Further studies on B. cereus $A 10$ needs to be reconsidered due to its weak antagonism against R. microporus, and its potency to be cause of the human disease.
\end{abstract}

Keywords: Endophytic bacteria; White Root Disease; identification; inhibition; R. microporus

\begin{abstract}
Abstrak
Salah satu cara pengendalian jamur akar putih (JAP) yang memiliki potensi besar untuk dikembangkan di masa mendatang adalah secara biologi dengan memanfaatkan mikroba antagonis. Pada berbagai komoditas termasuk tanaman karet, bakteri endofitik antagonis telah dimanfaatkan untuk menghambat pertumbuhan patogen. Penelitian ini dilakukan untuk mengeksplorasi, mengidentifikasi bakteri endofitik dari tanaman karet serta menguji potensinya sebagai antagonis terhadap Rigidoporus microporus. Lima isolat berhasil diisolasi dari tanaman sehat di areal endemik JAP (isolat A10, A14, A16) dan areal non endemik JAP (isolat GN1, GN2). Uji oposisi langsung menunjukkan isolat A10 memiliki zona penghambatan terbesar $(0,3$ $\mathrm{cm})$ pada 4 hari setelah inokulasi dibandingkan isolat lainnya. Identifikasi secara molekuler berdasarkan sekuens gen parsial 16S rRNA dan gen gyrase subunit B terhadap isolat A10 adalah Bacillus cereus. Aktivitas enzim protease ditunjukkan oleh isolat A10 pada medium skim milk dan kemampuannya mencairkan gelatin pada hari keenam setelah inokulasi. Kemampuan menghambat filtrat ekstraseluler yang diuji dengan metode paper disk belum menunjukkan zona penghambatan yang konsisten pada tiap konsentrasi filtrat ekstraseluler yang diberikan. Pada hari ketiga setelah inokulasi (HSI) tidak terdapat perbedaan nyata antar perlakuan. Pengujian
\end{abstract}


lebih lanjut terhadap $B$. cereus isolat A10 perlu dipertimbangkan kembali karena potensi antagonismenya yang masih lemah terhadap $R$. microporus dan adanya potensi lain sebagai penyebab penyakit bagi manusia.

Kata kunci: Bakteri endofit; Jamur Akar Putih; identifikasi; penghambatan; $R$. microporus

\section{PENDAHULUAN}

Penyakit Jamur Akar Putih (JAP) yang disebabkan oleh Rigidoporus microporus pada tahun 2014 mengakibatkan kerugian finansial yang dihitung secara nasional mencapai IDR 374 milyar dari luas serangan sekitar 87.599 Ha (Direktorat Jenderal Perkebunan [Ditjenbun], 2015). Upaya pengendalian yang dilakukan masih belum mampu mengatasi penyakit ini hingga tuntas dan membutuhkan asupan yang cukup besar sehingga tidak mampu diadopsi oleh masyarakat luas.

Salah satu cara pengendalian yang memiliki potensi untuk dikembangkan di masa mendatang yaitu dengan menggunakan agensia hayati. Pengendalian secara biologi ini memiliki banyak keuntungan, diantaranya ramah lingkungan, relatif murah, sesuai dengan konsep Pengendalian Hama Terpadu, terjaganya keseimbangan agro-ekosistem, dan mudah diaplikasikan baik di perkebunan besar maupun di tingkat petani. Agensia hayati yang paling banyak dimanfaatkan sebagai biofungisida saat ini adalah jamur dan bakteri. Di perkebunan karet, jamur adalah agensia hayati yang telah lama dikenal dengan potensinya sebagai biofungisida. Banyak jamur yang telah dijadikan sebagai biofungisida dan diproduksi secara komersial, salah satunya adalah Trichoderma spp. (Setyawan, Pawirosoemardjo, \& Hadi, 2013). Sedangkan bakteri yang memiliki daur hidup relatif lebih cepat dan potensi besar untuk dikembangkan masih dalam tahap penelitian dan pengembangan. Salah satu jenis bakteri yang bersimbiosis dengan tanaman tersebut adalah bakteri endofitik (Kuklinsky-Sobral, Araujo, Mendes, Pizzirani-Kleiner, \& Azevedo, 2005).
Upaya pencegahan dan pengendalian yang telah dilakukan untuk pengendalian JAP dimulai dengan tindakan pencegahan melalui pembongkaran tunggul dan pembersihan sisa-sisa akar tanaman sebelumnya, pengolahan tanah, penggunaan bibit bebas JAP, penanaman tanaman penutup tanah kacangan, penaburan belerang hingga tindakan pengendalian dengan menggunakan fungisida kimia maupun fungisida hayati atau biofungisida (Sujatno \& Pawirosoemardjo, 2001; Situmorang et al., 2007). Fakta di lapangan menunjukkan bahwa upaya tersebut masih banyak mengalami kendala, terutama dalam teknis pelaksanaan dan biayanya. Penelitian ini perlu dilakukan untuk mengeksplorasi potensi pengendalian secara biologi yang selama ini dikenal relatif murah dan mudah dalam pelaksanaannya.

Banyak penelitian yang mengindikasikan bahwa bakteri endofitik ada di berbagai macam jaringan pada banyak spesies tanaman. Bakteri endofitik hampir ada di setiap spesies tanaman dan dapat memberikan dampak positif bagi tanaman, misalnya untuk bertahan dari serangan patogen maupun memacu pertumbuhan tanaman misalnya sebagai pemicu pertumbuhan tanaman (plant growth-promoting bacteria) (Rashid, Charles, $\&$ Glick, 2012). Penggunaan bakteri endofitik pada tanaman semusim telah terbukti dapat menurunkan intensitas penyakit tertentu pada tanaman. Pereira, Nesci, dan Etcheverry (2007) dalam penelitiannya menyebutkan bahwa dengan perlakuan benih pada jagung menggunakan bakteri Bacillus amyloliquefaciens atau Microbacterium oleovorans pada konsentrasi $10^{9} \mathrm{cfu} / \mathrm{mL}$ dapat menurunkan jumlah propagul Fusarium verticillioides di dalam jaringan akar tanaman jagung. Tan et al (2015) telah berhasil mengisolasi bakteri endofitik dari tanaman karet yang menunjukkan potensi penghambatan hingga $70 \%$ terhadap penyakit layu Fusarium pada pisang.

Populasi bakteri endofitik yang berasal dari populasi epifit pada permukaan akar maupun permukaan daun yang diketahui mampu masuk ke dalam jaringan tanaman (endofit) dapat diinvestasikan ke 
bibit dan bahan tanam. Ketika berada di dalam jaringan tanaman, bakteri endofitik akan menempati bagian tertentu pada jaringan tanaman atau secara sistemik melakukan kolonisasi. Mikroorganisme tersebut dapat hidup di dalam sel, di ruang antar sel, atau pada sistem jaringan angkut tanaman. Beberapa genus yang dilaporkan sebagai bakteri endofitik yang diisolasi dari berbagai jenis tanaman antara lain Bacillus, Pseudomonas, Pantoea, Acinetobacter, Agrobacterium, Serratia, Burkholderia, Curtobacterium dan Sphingomonas (Li et al., 2008; Ulrich et al., 2008).

Penelitian ini dilakukan untuk mengeksplorasi dan mengidentifikasi isolat bakteri endofitik dari perakaran tanaman karet serta menguji potensinya sebagai antagonis terhadap $R$. microporus. Potensi antagonis diketahui dengan uji oposisi langsung, ada tidaknya aktivitas enzim protease dan kemampuan penghambatan oleh filtrat ekstraseluler isolat bakteri dengan metode paper disk.

\section{BAHAN DAN METODE}

Bahan tanaman yang digunakan dalam penelitian ini adalah sampel akar tanaman karet Tanaman Menghasilkan (TM) yang sehat di areal endemik JAP (fenotip pohon menyerupai tanaman seedling) di daerah Sikijang Mati, Riau, serta sampel akar tanaman karet sehat klon GT 1 di areal non endemik JAP, di Getas, Jawa Tengah. Bahan utama lainnya antara lain medium Tryptic Soy Agar (TSA), sodium hipoklorit teknis konsentrasi $1 \%$, isolat R. microporus SU-1 asal isolat Sumatera Utara, aquadest, medium skim milk, dan medium untuk uji pencairan gelatin. Bahan yang digunakan untuk mengekstraksi DNA kromosom bakteri yaitu larutan penyangga Tris-EDTA (100:50 mM), sodium dodecyl sulfate (SDS) $10 \%, \mathrm{NaCl} 5 \mathrm{M}, \mathrm{CTAB}+\mathrm{NaCl}$ solution, chloroform isoamyl alcohol 24:1 (CIAA), phenol chloroform $\mathrm{N}$ isoamyl alcohol (PCIAA), isopropanol, dan etanol $70 \%$. Bahan yang dipergunakan dalam proses amplifikasi/PCR meliputi DNA template, DreamTaq Green mastermix (Thermo Scientific), GoTaq Green Master Mix 2x (Promega, USA), nuclease free water, primer yang dipergunakan untuk identifikasi bakteri berdasarkan gen parsial 16S rRNA yaitu $27 \mathrm{~F}$ dan $1492 \mathrm{R}$, primer yang dipergunakan untuk identifikasi bakteri berdasarkan gen gyrase subunit B yaitu FgyrB dan R-gyrB. Sedangkan bahan untuk visualisasi hasil PCR dengan elektroforesis yaitu agarosa, TBE 1x buffer, larutan ethidium bromide (EtBr), loading buffer, dan 100bp DNA Ladder.

\section{Ekplorasi dan Pengujian Antagonisme secara In-Vitro}

Isolasi dilakukan dari bagian akar tanaman karet. Studi ini dimulai dengan melakukan koleksi isolat serta penapisan secara in vitro terhadap kemampuan untuk menekan perkembangan penyakit.

Isolasi bakteri endofitik dilakukan dengan cara mengambil $0,5 \mathrm{~g}$ bagian tanaman, selanjutnya didisinfeksi permukaannya dengan $1 \%$ sodium hipoklorit selama satu menit, kemudian bagian tanaman tersebut dicuci dengan air steril 4-5 kali untuk menghilangkan sisasisa yang menempel. Bahan yang telah didisinfeksi digiling dengan mortar steril dalam $10 \mathrm{ml}$ air steril. Larutan tersebut diteteskan pada cawan petri sebanyak satu tetes dan ditambahkan media Nutrient Agar (NA) atau Tryptic Soy Agar (TSA) yang masih cair $\left( \pm 45^{\circ} \mathrm{C}\right)$. Untuk meratakan distribusi inokulum bakteri, petri digoyang-goyang perlahan dan searah, kemudian diinkubasikan pada suhu $30 \pm 1^{\circ} \mathrm{C}$ selama 24 48 jam (Joseph \& Deka, 2007). Pemilihan media untuk pertumbuhan bakteri sangat penting karena memiliki pengaruh langsung terhadap jumlah dan jenis mikroorganisme yang dapat diisolasi dari jaringan akar. Untuk bakteri endofitik, pada umumnya menggunakan media TSA yang memiliki kisaran jenis bakteri cukup luas (Gardner et al., 1982 dalam Hallmann et al., 2006).

Kemampuan antagonisme isolat diketahui dengan uji oposisi langsung yang mengikuti metode Supriyanto, Priyatmojo, dan Arwiyanto (2011) yang dimodifikasi yaitu koloni jamur $R$. microporus yang telah dibor gabus dengan diameter $\pm 0,9 \mathrm{~cm}$ kemudian diinokulasikan di tengah cawan petri yang telah berisi media TSA. Selanjutnya isolat bakteri yang diuji digoreskan pada empat sisi bagian tepi cawan petri dengan jarak $2,5 \mathrm{~cm}$ dari inokulum jamur. Inkubasi pada suhu kamar dilakukan sampai koloni jamur pada perlakuan kontrol memenuhi cawan petri. 
Pengamatan dilakukan setiap hari dengan mengukur panjang pertumbuhan koloni jamur, yaitu dari tepi potongan inokulum awal $R$. microporus hingga ke ujung pertumbuhan koloni, serta zona penghambatan yang terbentuk.

\section{Identifikasi Isolat Terpilih Berdasarkan Sekuens Gen 16S rRNA dan gyrB}

Identifikasi secara molekuler dilakukan berdasarkan sekuens gen parsial 16S rRNA dan gen gyrase subunit B (gyrB). Aplikasi teknik molekuler untuk menganalisa keragaman mikroba, seperti analisis gen 16s-rRNA dengan polymerase chain reaction (PCR) mampu menampilkan keragaman genetika mikroba, baik yang dapat dikulturkan maupun tidak. Gen 16s rRNA merupakan pilihan karena gen ini terdapat pada semua prokariot dan memiliki bagian atau sekuen konservatif serta sekuen lainnya yang sangat bervariasi. Penggunaan gen parsial 16S rRNA masih cukup akurat dan cepat untuk mengetahui hubungan filogenetik bakteri dan keragaman komunitas mikrobia, sedangkan gen gyrB digunakan untuk membedakan hubungan antar spesies yang memiliki kekerabatan cukup dekat (Yin et al., 2008).

\section{Ekstraksi DNA}

Salah satu isolat bakteri dipilihsingle colony dari bakteri tersebut dan ditumbuhkan pada media Tryptic Soy Broth (TSB) dengan inkubasi menggunakan shaker selama $\pm 24-48$ jam. Selanjutnya ekstraksi DNA dilakukan sesuai dengan Nishiguchi et al. (2002) tanpa menggunakan larutan proteinase K. Pelet DNA diresuspensi dengan TE buffer sebanyak 20-40 $\mu \mathrm{L}$ dan disimpan pada $-20^{\circ} \mathrm{C}$.

\section{Amplifikasi PCR 16S rRNA dan gyrB}

Bakteri diidentifikasi berdasarkan gen parsial 16S rRNA dan gyrB. Proses identifikasi diawali dengan amplifikasi gen parsial 16S rRNA dengan PCR menggunakan $\mathrm{urutan}$ b a s a primer $27 \mathrm{~F}$ (5'-AGAGTTTGATCMTGGCTCAG-3') dan p r i m e r $14992 \mathrm{R} \quad$ ( $55^{\prime}$ TACGGYTACCTTGTTACGACTT-3'). Primer 27F dan 1492R menghasilkan amplikon gen parsial 16S rRNA bakteri berukuran \pm 1.475 bp. Komposisi campuran PCR untuk mengamplifikasi gen parsial 16S rRNA adalah GoTaq Green Master Mix sebanyak $25 \mu 1$, suspensi DNA sebanyak $5 \mu 1$, primer $27 \mathrm{~F}$ sebanyak $3 \mu \mathrm{l}$, primer 1492R $3 \mu \mathrm{l}$ dan nuclease free water $14 \mu \mathrm{l}$ sehingga volume akhir suspensi adalah $50 \mu$ l. PCR dilakukan menggunakan Thermal cycler dengan pengaturan denaturasi awal DNA cetakan $94^{\circ} \mathrm{C}$ selama 2 menit, diikuti dengan 34 siklus yang terdiri atas denaturasi (15 detik pada suhu $94^{\circ} \mathrm{C}$ ), annealing (30 detik pada suhu $57^{\circ} \mathrm{C}$ ), extension (30 detik pada suhu $68^{\circ} \mathrm{C}$ ), dan pada akhir siklus, final extension pada suhu $72{ }^{\circ} \mathrm{C}$ selama 5 menit.

Selanjutnya amplifikasi gen gyrase B dengan PCR menggunakan primer F-gyrB (5'-CCCAAGCTTAACTGCACTGGGAAATY-3')

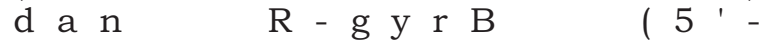
CGGAATTCGGATCCACRTCGGCRTCB-3'). Untuk amplifikasi gen gyrB mengikuti prosedur Yamamoto dan Harayama (1995). DNA hasil amplifikasi berukuran $\pm 1.335 \mathrm{bp}$ divisualisasi dengan elektroforesis pada $1 \%$ gel agarose (Sigma) (b/v) dalam 1x TBE bufferdengan $100 \mathrm{bp}$ dan $1 \mathrm{~kb}$ DNA ladder.

\section{Analisis data hasil sekuensing}

Sekuensing dilakukan dengan mengirim hasil PCR ke perusahaan $1^{\text {st }}$ BASE Malaysia. Hasil PCR dimasukkan ke dalam tabung ependorf kemudian diberi parafilm pada tutupnya. Tube yang berisi hasil PCR diletakkan di atas stereoform, kemudian dikemas dalam ice box, dan dikirimkan ke perusahaan $1^{\text {st }}$ BASE Malaysia. Sekuensing bertujuan untuk mengetahui urutan basa DNA isolat bakteri yang akan digunakan untuk melihat dan menentukan kekerabatan spesies isolat bakteri dengan basis data (database) bakteri yang ada pada GeneBank. Hasil sekuensing kromosom DNA bakteri yang diperoleh, dianalisis dan dibandingkan dengan basis data yang ada pada NCBI menggunakan Program BLAST untuk mengetahui homologi sekuens isolat bakteri tersebut dengan spesies bakteri lainnya. Selanjutnya dilakukan analisis hubungan similaritas dan filogenetik bakteri hasil sekuensing menggunakan program Software Mega 5. Setelah itu digunakan Program TreeView pada Mega 5 untuk memperoleh gambaran pohon filogenetik bakteri teridentifikasi. 


\section{Pengujian Aktivitas Enzim Protease}

1. Uji dalam medium skim milk

Pengujian ini dilakukan dengan menggunakan medium skim milk mengikuti Setyawan (2014) yang tediri dari $\mathrm{K}_{2} \mathrm{HPO}_{4}(0,7$ $\mathrm{g} / \mathrm{L}), \mathrm{KH}_{2} \mathrm{PO}_{4}(\mathrm{O}, 3 \mathrm{~g} / \mathrm{L}), \mathrm{MgSO}_{4} \cdot 7 \mathrm{H}_{2} \mathrm{O}(0,5$ $\mathrm{g} / \mathrm{L}), \mathrm{FeSO}_{4} \cdot 7 \mathrm{H}_{2} \mathrm{O}(0,01 \mathrm{~g} / \mathrm{L}), \mathrm{ZnSO}_{4}(0,001$ $\mathrm{g} / \mathrm{L})$, agar (15-20 g/L), dan skim milk $(2,5$ $\mathrm{g} / \mathrm{L})$. Isolat bakteri berumur 48 jam digoreskan pada medium uji kemudian diinkubasikan pada suhu kamar selama 2448 jam. Aktivitas enzim protease yang terjadi ditunjukkan dengan munculnya zona bening atau halo disekitar koloni bakteri.

\section{Uji pencairan gelatin}

Pengujian ini dilakukan mengikuti metode Chakraborty, Mahapatra, dan Roy (2011), yaitu dengan menusukkan jarum ose yang telah dicelupkan ke dalam suspensi bakteri uji pada medium gelatin dalam tabung reaksi. Medium gelatin yang digunakan terdiri dari beef extract $(3 \mathrm{~g} / \mathrm{L})$, peptone $(5 \mathrm{~g} / \mathrm{L})$ dan gelatin $(120 \mathrm{~g} / \mathrm{L})$. Media gelatin yang telah diinokulasi, diinkubasikan pada suhu $25^{\circ} \mathrm{C}$ dan dilakukan pengamatan setiap 2 hari sekali selama 14 hari. Pada saat pengamatan, tabung perlakuan dan tabung kontrol dimasukkan ke dalam lemari es yang bersuhu $4^{\circ} \mathrm{C}$ selama 30 menit hingga tabung kontrol yang ditusuk dengan air steril membeku. Aktivitas proteolitik isolat yang diuji ditunjukkan dengan mencairnya gelatin setelah dimasukkan ke dalam lemari es.

\section{Pengujian Antagonisme Ekstraseluler dengan Metode Cakram Kertas Saring (Filter Paper Disk)}

Filtrat isolat bakteri yang diuji dipersiapkan dengan ditumbuhkan terlebih dahulu pada medium Tryptic Soy Broth (TSB) selama 48 jam kemudian disentrifugasi dengan kecepatan $10.000 \mathrm{rpm}$ selama 2 menit dan filtrat yang diperoleh disaring menggunakan kertas filter dengan kerapatan 0,22 $\mu \mathrm{m}$. Selanjutnya filtrat dapat langsung digunakan atau disimpan pada suhu $-20^{\circ} \mathrm{C}$. Pengujian dilakukan dengan mengunakan medium TSA dalam cawan petri. Setelah medium mengeras, potongan koloni jamur akar putih berdiameter $0,9 \mathrm{~cm}$ diletakkan di tengah petri. Selanjutnya 4 cakram kertas saring steril berdiameter 0, 6 $\mathrm{cm}$ diletakkan di dalam petri dengan jarak 2 $\mathrm{cm}$ antara paper disk dan inokulum JAP. Pada setiap paper disk ditetesi dengan $20 \mu 1$ filtrat bakteri dengan berbagai konsentrasi filtrat, yaitu $100 \%, 75 \%, 50 \%$ dan $25 \%$ filtrat bakteri dalam air steril. Setiap perlakuan diberikan ulangan 3 cawan petri. Sebagai kontrol, paper disk ditetesi dengan $20 \mu 1$ air steril. Inkubasi dilakukan pada suhu kamar dan pengamatan zona penghambatan dilakukan setiap hari hingga koloni JAP dengan perlakuan kontrol memenuhi cawan petri.

\section{Rancangan Percobaan dan Analisa Data}

Rancangan percobaan dilakukan dengan Rancangan Acak Lengkap (RAL), masing-masing 3 ulangan setiap perlakuan. Data hasil pengujian dianalisis dengan one way anova dan diuji lanjut menggunakan Duncan Multiple Range Test pada taraf 5\% dalam Program Statistical Analysis System (SAS).

\section{HASIL DAN PEMBAHASAN}

\section{Ekplorasi dan Pengujian Antagonisme secara In-Vitro}

Eksplorasi yang dilakukan dari bagian akar tanaman karet sehat diperoleh 5 isolat bakteri endofitik, yaitu 3 isolat berasal dari areal endemik jamur akar putih (A10, A14 dan A16) dan 2 isolat berasal dari daerah non endemik (GN1 dan GN2). Isolat tersebut menunjukkan respon antagonis terhadap JAP yang sama pada hari keempat setelah inokulasi, kecuali isolat A10 yang memiliki zona penghambatan $0,3 \mathrm{~cm}$ (Tabel 1).

Pengamatan juga dilakukan terhadap pertumbuhan miselium $R$. microporus hingga 3 hari setelah inokulasi karena pada pengamatan hari ke-4 sebagian perlakuan dan kontrol telah memenuhi cawan petri. Pertumbuhan miselium $R$. microporus terlihat paling lambat pada perlakuan isolat A10 yang tidak berbeda nyata dengan isolat A14 dan A16 (Tabel 2). 
Tabel 1. Zona penghambatan beberapa isolat bakteri endofitik dengan uji oposisi langsung terhadap jamur akar putih $R$. microporus pada medium TSA

Table 1. The direct inhibition zone of bacterial isolates against R. microporus on TSA medium

\begin{tabular}{|c|c|c|c|}
\hline \multirow{2}{*}{$\begin{array}{l}\text { Isolat } \\
\text { Isolate }\end{array}$} & \multicolumn{3}{|c|}{$\begin{array}{c}\text { Rerata zona penghambatan } \\
\text { Inhibition zone } \\
(\mathrm{cm})\end{array}$} \\
\hline & $\begin{array}{l}2 \mathrm{HSI} \\
2 \mathrm{DAI}\end{array}$ & $\begin{array}{l}3 \mathrm{HSI} \\
3 \mathrm{DAI}\end{array}$ & $\begin{array}{l}4 \mathrm{HSI} \\
4 \mathrm{DAI}\end{array}$ \\
\hline A10 & $0,8 \mathrm{a}$ & $0,4 \mathrm{a}$ & $0,3 \mathrm{a}$ \\
\hline A 14 & $0,3 \mathrm{~b}$ & $0,1 \mathrm{bc}$ & $0,0 \mathrm{~b}$ \\
\hline A16 & $0,4 \mathrm{~b}$ & $0,2 \mathrm{~b}$ & $0,0 \mathrm{~b}$ \\
\hline GN1 & $0,3 \mathrm{~b}$ & $0,0 \mathrm{c}$ & $0,0 \mathrm{~b}$ \\
\hline GN2 & $0,6 \mathrm{a}$ & $0,0 \mathrm{c}$ & $0,0 \mathrm{~b}$ \\
\hline Kontrol & $0,0 \mathrm{c}$ & $0,0 \mathrm{c}$ & $0,0 \mathrm{~b}$ \\
\hline
\end{tabular}

Keterangan (Remarks):

1. Angka yang diikuti huruf yang sama dalam satu kolom tidak berbeda nyata berdasarkan uji Duncan Multiple Range Test pada tingkat kepercayaan 95\% (Figures followed by the same letter in the same column indicates no significant difference based on DMRT at 95\% level)

2. HSI = Hari Setelah Inokulasi (DAI= Days AfterInoculation $)$

Tabel 2. Pertumbuhan koloni jamur akar putih $R$. microporus dengan uji oposisi langsung beberapa isolat bakteri endofitik pada medium TSA

Table 2. R. microporus culture growth on direct opposition test to several bacterial isolates on TSA medium.

\begin{tabular}{|c|c|c|}
\hline \multirow{2}{*}{$\begin{array}{l}\text { Isolat } \\
\text { Isolate }\end{array}$} & \multicolumn{2}{|c|}{$\begin{array}{c}\text { Pertumbuhan koloni jamur } \\
\text { Fungal colony growth } \\
\text { (cm) }\end{array}$} \\
\hline & $\begin{array}{l}2 \mathrm{HSI} \\
2 \mathrm{DAI}\end{array}$ & $\begin{array}{l}3 \text { HSI } \\
3 \mathrm{DAI}\end{array}$ \\
\hline A10 & $1,7 \mathrm{~cd}$ & $2,2 \mathrm{~d}$ \\
\hline A14 & $2,2 \mathrm{~b}$ & $2,2 \mathrm{~d}$ \\
\hline A16 & $1,9 \mathrm{bc}$ & $2,2 \mathrm{~d}$ \\
\hline GN 1 & $2,0 \mathrm{bc}$ & $2,4 \mathrm{c}$ \\
\hline GN2 & $1,7 \mathrm{~d}$ & $2,8 \mathrm{~b}$ \\
\hline Kontrol & $2,7 \mathrm{a}$ & $4,2 \mathrm{a}$ \\
\hline
\end{tabular}

Keterangan (Remarks):

1. Angka yang diikuti huruf yang sama dalam satu kolom tidak berbeda nyata berdasarkan uji Duncan Multiple Range Test pada tingkat kepercayaan 95\% (Figures followed by the same letter in the same column indicates no significant difference based on DMRT at 95\% level)

2. HSI = Hari Setelah Inokulasi (DAI= Days After Inoculation)

\section{Identifikasi Berdasarkan Sekuens Gen 16S rRNA dan gyrB}

Identifikasi secara molekuler dilakukan terhadap isolat A10 yang mewakili isolat bakteri endofitik berasal dari tanaman sehat di areal endemik jamur akar putih. Identifikasi dilakukan berdasarkan sekuens gen 16S rRNA dan gyrase B. Hasil PCR menggunakan urutan basa primer $16 \mathrm{~S}$ rRNA 27F (5'-AGAGTTTGATCMTGGCTCAG$\left.3{ }^{\prime}\right) \mathrm{d}$ a $\mathrm{n} 1492 \mathrm{R} \quad\left(5^{\prime}\right.$ TACGGYTACCTTGTTACGACTT-3'), dan primer gyrase B, yaitu F-gyrB (5'-
CCCAAGCTTAACTGCACTGGGAAATY-3') d a $n \quad R-g$ y r B ( $5^{\prime}$ CGGAATTCGGATCCACRTCGGCRTCB-3') menunjukkan bahwa DNA isolat A10 mampu teramplifikasi menggunakan primer $16 \mathrm{~S}$ rRNA dengan panjang basa $\pm 1.475 \mathrm{bp}$ dan menggunakan primer gyrB pada $\pm 1.335 \mathrm{bp}$. Visualisasi hasil PCR gen 16S rRNA dan GyrB yang menggunakan gel agarosa $1 \%$ dibawah UV Transluminator dapat dilihat pada Gambar 1.

Produk PCR dengan kedua primer tersebut selanjutnya disekuensing untuk 


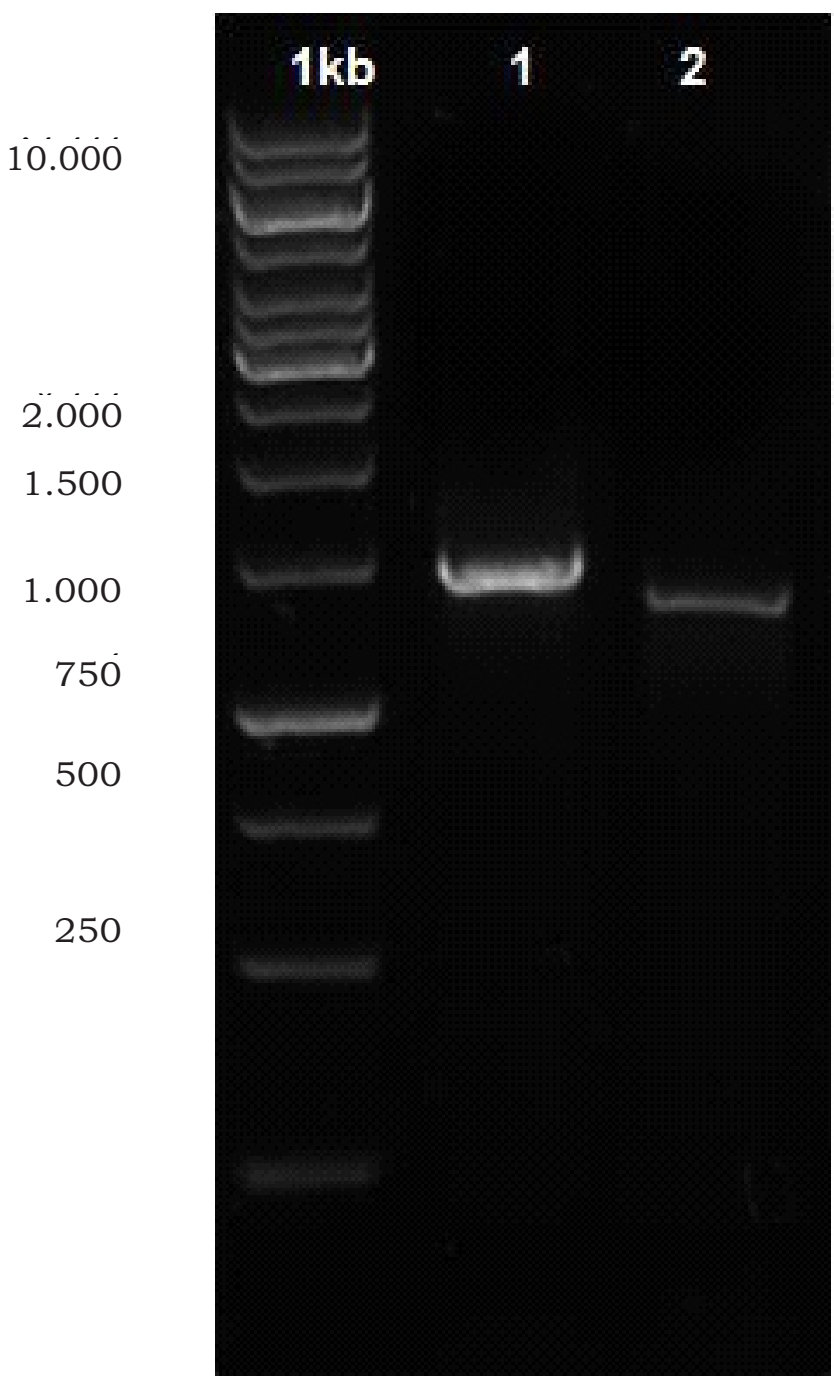

Gambar 1. Visualisasi hasil PCR isolat A10 menggunakan primer 16S rRNA dan gyrB.

Figure 1. Agarose gel electrophoresis of PCR product based on 16S rRNA and gyrB gene of isolate A10.

Keterangan (Remarks):

1. $1 \mathrm{~kb}=$ marker $(1 \mathrm{~kb}=$ marker $)$

2. $1=16 \mathrm{~S} \mathrm{rRNA} \pm 1.475 \mathrm{bp}(1=16 \mathrm{~S} r R N A \pm 1.475 \mathrm{bp})$

3. $2=\operatorname{gyrB} \pm 1.335 \mathrm{bp}(2=\operatorname{gyr} B \pm 1.335 \mathrm{bp})$

mengetahui urutan basa DNA isolat bakteri, dalam hal ini isolat A10, yang akan digunakan untuk menentukan hubungan kekerabatan spesies isolat bakteri dengan database DNA bakteri yang berada di GeneBank. Hasil sekuensing DNA bakteri dianalisis dan dibandingkan dengan database yang ada pada NCBI menggunakan program BLAST untuk mengetahui homologinya terhadap spesies bakteri lainnya. Homologi sekuens isolat A10 berdasarkan gen 16S rRNA dapat dilihat pada Tabel 3.
Berdasarkan sekuens gen 16S rRNA, isolat A10 termasuk atau mirip dengan isolat Bacillus cereus ATCC 14579 dengan homologi 99,93\%. Selanjutnya dilakukan analisis hubungan similaritas dan filogenetik bakteri Bacillus spp. (isolat A10) hasil sekuensing dengan menggunakan Program Mega 5. Hasil analisis hubungan filogenetik bakteri Bacillus spp. berdasarkan gen 16S rRNA dapat dilihat pada Gambar 2. 
Tabe1 3. Homologi sekuens gen 16S rRNA isolat A10 dengan menggunakan Program BLAST Table 3. 16S rRNA gene sequence similarity of isolate A1O using BLAST Program

\begin{tabular}{rlcc}
\hline No. & \multicolumn{1}{c}{$\begin{array}{c}\text { Isolat } \\
\text { Isolate }\end{array}$} & $\begin{array}{c}\text { Homologi } \\
\text { Homology } \\
(\%)\end{array}$ & $\begin{array}{c}\text { Kode akses } \\
\text { Accession code }\end{array}$ \\
\hline 1 & Bacillus cereus ATCC 14579* & 99,93 & NR_074540 \\
2 & Bacillus thuringiensis NBRC 101235* & 99,85 & AB4264779 \\
3 & Bacillus anthracis Ames & 99,78 & NR_074453 \\
4 & Bacillus weihenstephanensis DSM11821* & 99,49 & NR_024697 \\
5 & Bacillus mycoidesC2 & 99,49 & AY373357 \\
6 & Bacillus subtilis subsp. spizizenii DSM 6405 & 94,34 & DQ195067 \\
7 & Bacillus mojavensis IFO15718* & 94,27 & NR_024693 \\
8 & Bacillus vallismortis DSM11031* & 94,27 & NR_024696 \\
9 & Bacillus amyloliquefaciens NBRC 15535* & 94,20 & NR_041455 \\
10 & Paenibacillus polymyxa DSM 36T* & 87,51 & HG324077 \\
\hline
\end{tabular}

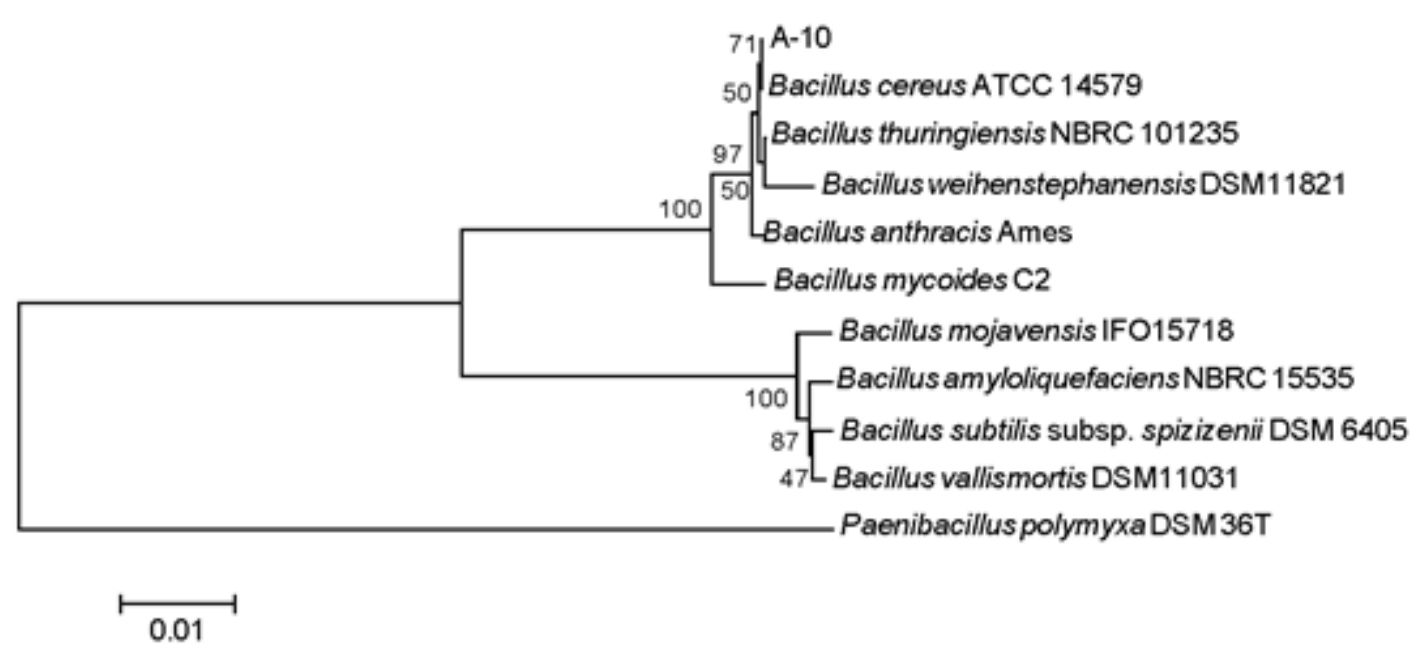

Gambar 2. Hasil analisis hubungan filogenetik sekuens bakteri Bacillus spp. dan isolat A10 berdasarkan gen 16S rRNA. Isolat A10 menjadi satu kelompok dengan Bacillus cereus ATCC 14579.

Figure 2. The phylogenetic tree based on 16S rRNA gene of Bacillus spp. included the isolates of A10. Isolate A10 was grouped and closely related to Bacillus cereus ATCC 14579.

Hasil analisis filogenetik sekuens gen 16S rRNA bakteri isolat A10 memiliki hubungan kekerabatan yang dekat dengan spesies bakteri Bacillus cereus ATCC 14579. Hal ini menunjukkan bahwa pada sekuens bakteri A10 berdasar gen 16S rRNA cukup konsisten sebagai Bacillus cereus baik berdasarkan homologi maupun dengan analisis filogenetik. Selanjutnya homologi sekuens bakteri Bacillus spp. atau isolat A10 juga dianalisis berdasarkan sekuens gen gyrB. Secara lengkap nilai homologinya dapat dilihat seperti pada Tabel 4.
Sekuens bakteri isolat A10 berdasarkan gen DNA gyrase subunit B masih menunjukkan hasil yang sama dengan sekuens berdasarkan gen 16S rRNA. Isolat A10 termasuk atau mirip dengan isolat Bacillus cereus ATCC 14579 dengan homologi 92,34\%. Selanjutnya dilakukan analisis hubungan similaritas dan filogenetik bakteri Bacillus spp. hasil sekuensing tersebut menggunakan Program Mega 5. Menurut analisis hubungan filogenetik ini, sekuens bakteri Bacillus spp. berdasarkan gen gyrB juga memiliki hubungan kekerabatan yang dekat dengan Bacillus cereus ATCC 14579 seperti tampak pada Gambar 3. 
Tabel 4. Homologi sekuens gen gyrB isolat A10 menggunakan Program BLAST Table 4. GyrB gene sequence similarity of isolate A10 using BLAST Program

\begin{tabular}{clcc}
\hline No & \multicolumn{1}{c}{$\begin{array}{c}\text { Isolat } \\
\text { Isolate }\end{array}$} & $\begin{array}{c}\text { Homologi } \\
\text { Homology } \\
(\%)\end{array}$ & $\begin{array}{c}\text { Kode akses } \\
\text { Accession No. }\end{array}$ \\
\hline 1 & Bacillus cereus ATCC 14579* & 92,34 & AB014101 \\
2 & Bacillus mycoides BGSC 6A13 & 86,51 & EF210250 \\
3 & Bacillus anthracis CI & 86,43 & DQ497181 \\
4 & Bacillus anthracis H0001 & 85,64 & AB190227 \\
5 & Bacillus thuringiensis ATCC 10792* & 83,17 & FR850503 \\
6 & Bacillus subtilis subsp. subtilis BCRC 10255* & 67,03 & DQ309293 \\
7 & Paenibacillus polymyxa IAM 13419* & 58,33 & AB464839 \\
\hline
\end{tabular}

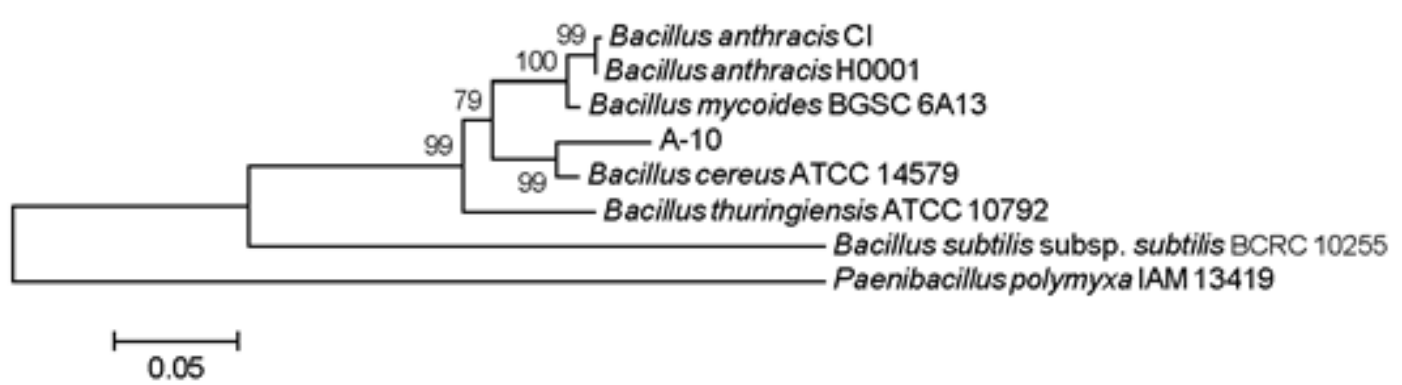

Gambar 3. Hasil analisis hubungan filogenetik sekuens bakteri Bacillus spp. dan isolat A10 berdasarkan gen GyrB. Isolat A10 menjadi satu kelompok dengan Bacillus cereus ATCC 14579.

Figure 3. The phylogenetic tree based on gyrB gene of Bacillus spp. included the isolates of A10. Isolate A10 was grouped and closely related to Bacillus cereus ATCC 14579.

Berdasarkan analisis filogenetik gen $16 \mathrm{~S}$ rRNA dan gyrase sub unit B, isolat A10 termasuk satu kelompok dengan bakteri Bacillus cereus. Berbeda dengan hasil pengujian reaksi gram dengan $\mathrm{KOH} 3 \%$ yang menunjukkan bahwa isolat A10 termasuk gram negatif, Bacillus cereus pada umumnya termasuk bakteri gram positif (Senesi \& Ghelardi, 2010; Tallent et al., 2012). B. cereus tersebar luas pada berbagai lingkungan, terutama di dalam tanah, dan dapat bertahan lama dalam berbagai kondisi lingkungan. Bakteri tersebut juga ditemukan di dalam jaringan tanaman sebagai bakteri endofit, seperti yang diisolasi oleh Zhao et al. (2011) dari tanaman Sophora alopecuroides.

Pada penelitian yang dilakukan oleh Li, Ma, Liu dan Zhang (2012), Bacillus cereus strain B-02 memiliki mekanisme antagonistik terhadap jamur Botrytis cinerea yang terdeteksi secara mikroskopik dengan adanya perubahan pada morfologi, ultrastruktur dan fisiologi hifa jamur $B$. cinerea. Beberapa isolat bakteri endofitik $B$. cereus diketahui menunjukkan aktivitas antifungal terhadap beberapa jamur patogen tanaman seperti Fusarium oxysporum dan Magnaphorthe grisea (Zhao et al., 2011).

B. cereus dapat memiliki siklus hidup sebagai saprofit seumur hidupnya, tetapi bakteri ini juga berpotensi sebagai patogen yang menyebabkan sakit pada manusia, terutama sebagai penyebab keracunan makanan yang ditandai dengan diare, gangguan perut, mual atau muntah, yang sebagian besar terjadi pada orang yang kurang sehat, memiliki penyakit kritis atau memiliki kekebalan tubuh yang lemah (McIntyre et al., 2008; Senesi \& Ghelardi, 2010; Tallent et al., 2012;).

\section{Pengujian Aktivitas Enzim Protease}

1. Uji dalam medium skim milk

Medium skim milk merupakan medium yang terdiri atas nutrient agar yang ditambahkan susu yang mengandung kasein. Kasein adalah protein yang mendominasi susu dan merupakan makromolekul yang terdiri atas asam amino 
yang dihubungkan oleh ikatan peptida. Enzim proteolitik yang disebut juga protease atau proteinase, merupakan enzim yang mampu memecah rantai panjang protein menjadi molekul yang lebih kecil (peptida) atau bahkan menjadi komponen terkecil penyusun protein (asam amino).

Hasil pengujian Bacillus cereus isolat A10 pada medium skim milk menunjukkan adanya aktivitas enzim protease yang sangat lemah ditandai dengan adanya zona bening yang tipis di sekitar koloni, dibandingkan dengan kontrol positif (Gambar 4). Nabrdalik, Grata, dan Latala (2010) juga menyebutkan bahwa salah satu isolat Bacillus cereus yang diujinya, yaitu isolat G10, tumbuh optimum dan dapat mengekspresikan aktivitas proteolitik pada medium skim milk hanya pada suhu $40^{\circ} \mathrm{C}$ dan $50^{\circ} \mathrm{C}$. Sedangkan pada suhu $30^{\circ} \mathrm{C}$, isolat tersebut menunjukkan aktivitas proteolitik yang sangat rendah pada medium skim milk.

\section{Uji pencairan gelatin}

Gelatin merupakan salah satu substrat yang mengandung protein sehingga dapat digunakan untuk menguji ada tidaknya aktivitas proteolitik bakteri. Medium gelatin semi-solid akan meleleh atau mencair pada suhu di atas $28^{\circ} \mathrm{C}$ (Anonim, 2014), namun akan segera membeku kembali apabila dimasukkan ke dalam lemari pendingin.
Hasil pengujian menunjukkan bahwa bakteri isolat Bacillus cereus A10 mampu manghasilkan enzim gelatinase atau menunjukkan aktivitas proteolitik setelah masa inkubasi 6 hari (Tabel 5). Aktivitas tersebut ditandai dengan mencairnya medium gelatin yang diinokulasi tusuk dengan Bacillus cereus isolat A10 setelah dimasukkan ke dalam lemari pendingin selama \pm 30 menit, pada hari ke-6 setelah inokulasi (Gambar 5B). Pada pengamatan hari kedua dan keempat setelah inokulasi, medium gelatin masih belum terhidrolisis dan padat (Gambar 5A). Sementara itu medium gelatin yang ditusuk dengan air steril tetap padat setelah dimasukkan ke dalam lemari pendingan, baik pada hari kedua hingga hari keempat belas setelah inokulasi

Berdasarkan hasil pengujian tersebut tampak bahwa Bacillus cereus isolat A10 dapat menghasilkan enzim gelatinase dengan kecepatan yang lambat. Bacillus spp. pada umumnya dapat menghasilkan enzim gelatinase pada periode inkubasi 8-96 jam (optimum 48 jam), $\mathrm{pH}$ medium 4-9 (optimum 7,5), suhu optimum pada $35^{\circ} \mathrm{C}$, dengan sumber karbon yang berasal dari 0,8\% laktosa (Balan, Nethaji, Sankar, \& Jayalakshmi, 2012). Menurut Kebabci dan Cihangir (2011), aktivitas protease yang tertinggi dari isolat Bacillus cereus yang diujinya adalah pada suhu $30^{\circ} \mathrm{C}$ dan $\mathrm{pH} 6,4$.
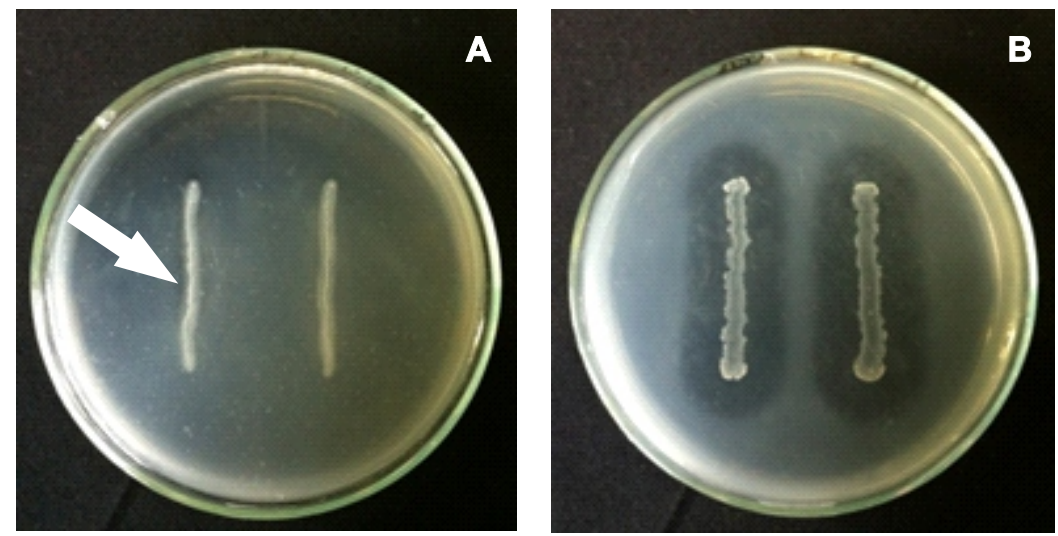

Gambar 4. Aktivitas enzim protease isolat B. cereus A10 pada medium skim milk (A) yang ditandai dengan adanya zona bening yang tipis di sekitar koloni (tanda panah), dibandingkan dengan kontrol positif dengan zona bening yang lebar (B).

Figure 4. Protease activity of $\mathrm{B}$. cereus $A 10$ was marked by a thin clear zone on skim milk medium (A) compared to the wide distinctive protease activity (B). 
Tabel 5. Hasil uji pencairan gelatin B. cereus isolat A10

Table 5. Gelatine liquefaction test result by B. cereus $A 10$

\begin{tabular}{ccc}
\hline Masa Inkubasi (hari) & Kontrol & A10 \\
Incubation period (day) & Control & - \\
2 & - & - \\
6 & - & + \\
8 & - & + \\
10 & - & + \\
12 & - & + \\
14 & - & + \\
\hline
\end{tabular}

Keterangan (Remarks):

1. $\quad+=$ gelatin mencair $(+=$ gelatine melted $)$

2. $\quad-\quad-=$ gelatin membeku $(-=$ gelatine solidified $)$
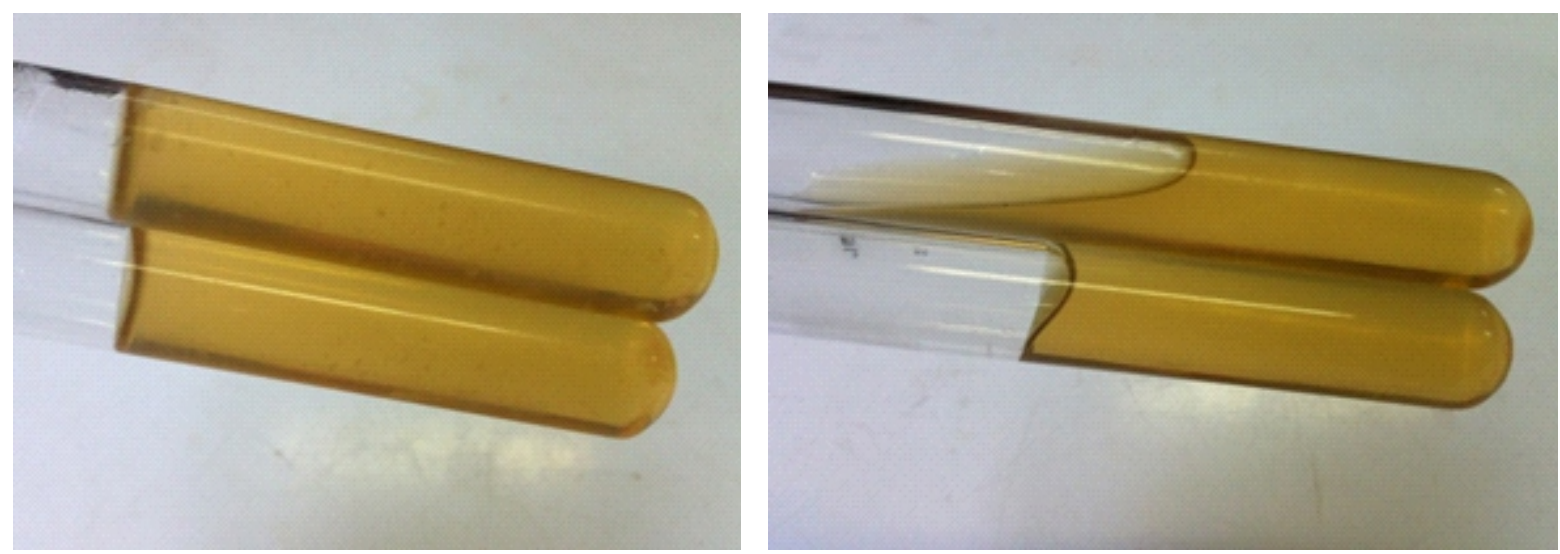

Gambar 5. Hasil uji pencairan gelatin dengan masa inkubasi 2 dan 4 hari (A) dan adanya aktivitas proteolitik $B$. cereus isolat A10 yang ditunjukkan dengan mencairnya gelatin mulai hari ke-6 (B).

Figure 5. Gelatine liquefaction by B. cereus $A 10$ with an incubation period of 2 and 4 days (A) and the melting of gelatine starting on day $6(B)$.

Genus Bacillus memiliki mekanisme penghambatan terhadap jamur yang sangat bervariasi, misalnya dengan menghasilkan berbagai jenis antibiotik, maupun enzim pendegradasi dinding sel seperti protease, lipase, kitinase dan glukanase (Li \& Jiang, 2006; Li et al., 2012).

\section{Pengujian Antagonisme Ekstraseluler dengan Metode Filter Paper Disk}

Pengujian dilakukan untuk mengetahui kemampuan penghambatan secara ekstraseluler atau aktivitas beberapa antibiotik maupun enzim pendegradasi dinding sel yang dihasilkan oleh Bacillus cereus A10 terhadap pertumbuhan miselium $R$. microporus. Parameter pengamatan uji penghambatan dengan metode filter paper disk ini yaitu pertumbuhan miselium dan zona penghambatan yang terbentuk. Hasil pengujian menunjukkan bahwa pada zona penghambatan hanya terbentuk hingga hari ke-2 setelah inokulasi pada konsentrasi $75 \%$ suspensi ekstraseluler dalam aquades steril. Hasil ini belum konsisten karena pada konsentrasi tertinggi (100\%) tidak terbentuk zona penghambatan. Dan pada hari ketiga tidak terdapat adanya zona penghambatan pada semua konsentrasi (Tabel 6). Pertumbuhan miselium $R$. microporus juga tampak belum memberikan hasil yang konsisten sesuai perlakuan konsentrasi dan tidak terjadi penghambatan yang berarti (Tabel 7).

Hasil pengujian di atas masih sesuai dengan pengujian oposisi langsung di awal penelitian, dimana Bacillus cereus isolat A10 memiliki tingkat antagonisme yang lemah terhadap jamur akar putih R. microporus dan aktivitas uji protease yang cukup lambat. Selain itu terdapat beberapa hal yang dapat mempengaruhi hasil di atas, antara lain 
Tabel 6. Zona penghambatan berbagai konsentrasi filtrat B. cereus isolat A10 dengan metode filter paper disk terhadap jamur akar putih $R$. microporus pada medium TSA

Table 6. Inhibition zone of R. microporus culture by extracellular filtrate of $\mathrm{B}$. cereus $\mathrm{A} 10$ using filter paper disk method on TSA medium

\begin{tabular}{cccc}
\hline $\begin{array}{c}\text { Konsentrasi } \\
\text { Concentration } \\
(\%)\end{array}$ & \multicolumn{3}{c}{$\begin{array}{c}\text { Rerata zona penghambatan } \\
\text { Inhibition zone } \\
(\mathrm{cm})\end{array}$} \\
\cline { 2 - 4 } & $1 \mathrm{HSI}$ & $2 \mathrm{HSI}$ & $3 \mathrm{HSI}$ \\
\hline 100 & $1 \mathrm{DAI}$ & $2 \mathrm{DAI}$ & $3 \mathrm{DAI}$ \\
75 & $1,4 \mathrm{~b}$ & $0,0 \mathrm{~b}$ & $0,0 \mathrm{a}$ \\
50 & $1,7 \mathrm{a}$ & $0,1 \mathrm{a}$ & $0,0 \mathrm{a}$ \\
25 & $1,4 \mathrm{~b}$ & $0,0 \mathrm{~b}$ & $0,0 \mathrm{a}$ \\
0 (Kontrol) & $1,4 \mathrm{~b}$ & $0,0 \mathrm{~b}$ & $0,0 \mathrm{a}$ \\
& $1,4 \mathrm{~b}$ & $0,0 \mathrm{~b}$ & $0,0 \mathrm{a}$ \\
\hline
\end{tabular}

Keterangan (Remarks):

1. Angka yang diikuti huruf yang sama dalam satu kolom tidak berbeda nyata berdasarkan uji Duncan Multiple Range Test pada tingkat kepercayaan 95\% (Figures followed by the same letter in the same column indicates no significant difference based on DMRT at 95\% level)

2. $\mathrm{HSI}=$ Hari Setelah Inokulasi (DAI= Days After Inoculation $)$

Tabel 7. Pertumbuhan miselium jamur akar putih $R$. microporus dengan uji oposisi langsung filtrat Bacillus cereus isolat A10 dengan metode filter paper disk pada medium TSA

Table 7. R. microporus culture growth shown on direct opposition test against extracellular filtrate of $\mathrm{B}$. cereus A1O using filter paper disk method on TSA medium

\begin{tabular}{cccc}
\hline $\begin{array}{c}\text { Konsentrasi } \\
\begin{array}{c}\text { Concentration } \\
(\%)\end{array}\end{array}$ & \multicolumn{3}{c}{$\begin{array}{c}\text { Rerata pertumbuhan koloni } \\
\text { Fungal culture growth } \\
(\mathrm{cm})\end{array}$} \\
\cline { 2 - 4 } & $1 \mathrm{HSI}$ & $2 \mathrm{HSI}$ & $3 \mathrm{HSI}$ \\
\hline 100 & $1 \mathrm{DAI}$ & $2 \mathrm{DAI}$ & $3,8 \mathrm{a}$ \\
75 & $0,6 \mathrm{a}$ & $2,3 \mathrm{a}$ & $3,5 \mathrm{~b}$ \\
50 & $0,3 \mathrm{~b}$ & $2,0 \mathrm{~b}$ & $3,8 \mathrm{a}$ \\
25 & $0,6 \mathrm{a}$ & $2,3 \mathrm{a}$ & $3,9 \mathrm{a}$ \\
0 (Kontrol) & $0,7 \mathrm{a}$ & $2,4 \mathrm{a}$ & $3,9 \mathrm{a}$ \\
\hline
\end{tabular}

Keterangan (Remarks):

1. Angka yang diikuti huruf yang sama dalam satu kolom tidak berbeda nyata berdasarkan uji Duncan Multiple Range Test pada tingkat kepercayaan 95\% (Figures followed by the same letter in the same column indicates no significant difference based on DMRT at 95\% level)

2. $\mathrm{HSI}=$ Hari Setelah Inokulasi (DAI= Days After Inoculation $)$

diduga konsentrasi suspensi ekstraseluler yang digunakan masih terlalu rendah dan adanya kerusakan enzim atau senyawa lain yang berperan karena penyimpanan dalam suhu $-20^{\circ} \mathrm{C}$ sebelum digunakan.

\section{KESIMPULAN}

Bakteri endofitik isolat A10 mampu menghambat pertumbuhan koloni jamur $R$. microporus secara invitro, dengan penghambatan yang lemah. Isolat tersebut mampu menghasilkan enzim ekstraseluler seperti protease dan gelatinase, tetapi masih belum memberikan penghambatan yang nyata terhadap koloni $R$. microporus pada pengujian filtrat ekstraseluler melalui metode cakram kertas saring. Berdasarkan identifikasi molekuler sekuens gen 16S rRNA dan gen gyrase subunit $\mathrm{B}$, isolat A10 termasuk ke dalam kelompok bakteri Bacillus cereus.

\section{UCAPAN TERIMA KASIH}

Ucapan terima kasih disampaikan kepada Balai Penelitian Getas, Pusat Penelitian Karet, atas bantuan dana In House sehingga dapat terlaksananya penelitian ini. Selain itu ucapan terima kasih 
juga disampaikan kepada Laboratorium Bakteriologi Tumbuhan Jurusan Perlindungan Tanaman Fakultas Pertanian Universitas Gadjah Mada atas dukungan tempat dan fasilitas laboratorium yang diberikan.

\section{DAFTAR PUSTAKA}

Anonim. (2014). Gelatinase Test. http://www.hccfl.edu. Diakses tanggal 31 Januari 2014.

Balan, S. S., Nethaji, R., Sankar, S., \& Jayalakshmi, S. (2012). Production of gelatinase enzyme from Bacillus spp. isolated from the sediment sample of Porto Novo Coastal sites. Asian Pacific Journal of Tropical Biomedicine, 2(3), 1811-1816. Doi: 10.1016/S22211691(12)60500-0

Chakraborty, S. P., Mahapatra, S. K., \& Roy, S. (2011). Biochemical characters and antibiotic susceptibility of Staphylococcus aureus isolates. Asian Pacific Journal of Tropical Biomedicine, 1(3), 212-216. Doi: 10.1016/S22211691(11)60029-4

Direktorat Jenderal Perkebunan. (2015). Data luas serangan OPT karet nasional dan taksasi kerugian hasil. Jakarta, Indonesia: Ditjenbun.

Hallmann, J., Berg, G., \& Schulz, B. (2006). Isolation procedures for endophytic microorganism. In: Schulz, B., Boyle, C., \& Sieber, T. N. (eds.). Soil Biology, Volume 9, Microbial Root Endophytes. Berlin, Germany: Springer-Verlag Berlin Heidelberg.

Joseph, K., \& Deka, H. K. (2007). Biocontrol techniques. In: Jacob, C. K., Srinivas, P., \& Roy, C. B. (eds.). A Laboratory manual for international training on strategies for management of Corynespora Leaf Fall Disease of Hevea brasiliensis. Kottayam, India: Rubber Research Institute of India.

Kebabci, O., \& Cihangir, N. (2011). Isolation of protease producing novel Bacillus cereus and detection of optimal conditions. African Journal of Biotechnology, 10(7), 1160-1164.
Kuklinsky-Sobral, J., Araujo, W. L., Mendes, R., Pizzirani-Kleiner, A. A., \& Azevedo, J. L. (2005). Isolation and characterization of endophytic bacteria from soybean (Glycine max) grown in soil treated with glyphosate herbicide. Plant and Soil, 273(1), 91-99. Doi: $10.1007 /$ s $11104-004-$ 6894-1.

Li, W. J., \& Jiang, R. B. (2006). The isolation and characteristic analysis of antagonistic substance produced by Brevibacillus laterosporus X10. Journal of Biology, 23, 16-19.

Li, J. H., Wang, E. T., Chen, W. F., \& Chen, W. X. (2008). Genetic diversity and potential for promotion of plant growth detected in nodule endophytic bacteria of soybean grown in Heilongjiang province of China. Soil Biology \& Biochemistry, 40(1), 238-246. Doi: 10.1016/j.soilbio.2007.08.014

Li, F. X., Ma, H. Q., Liu, J., \& Zhang, C. (2012). Antagonistic effects of Bacillus cereus strain B-02 on morphology, ultrastructure and cytophysiology of Botrytis cinerea. Polish Journal of Microbiology, 61(2), 119-128.

McIntyre, L., Bernard, K., Beniac, D., IsaacRenton, J. L., \& Naseby, D. C. (2008). Identification of Bacillus cereus group species associated with food poisoning outbreaks in British Columbia, Canada. Appl. Environ. Microbiol., $74(23), 7451-7453$. D o i : 10.1128/AEM.01284-08.

Nabrdalik, M., Grata, K., \& Latala, A. (2010). Proteolytic activity of Bacillus cereus strains. Proceedings of ECOpole 4(2), 273-277.

Nishiguchi, M. K., Doukakis, P., Egan, M., Kizirian, D., Phillips, A., Prendini, L., Rosenbaum, H. C., Torres, E., Wyner, Y., DeSalle, R., \& Giribet, G. (2002). DNA isolation Protocols. In: DeSalle, R., Wheeler, W., \& Giribet, G (eds.). Techniques in Molecular Systematics and Evolution. Basel, Germany: Birkhäuser. 
Pereira, P., Nesci, A., \& Etcheverry, M. G. (2007). Efficacy of bacterial seed treatments for the control of Fusarium verticillioides in maize. Rio Cuarto, Brazil: Springer.

Rashid, S., Charles, T. C. \& Glick, B. R. (2012). Isolation and characterization of new plant growth-promoting bacterial endophytes. Applied Soil Ecology, 61, 217-224. Doi: 10.1016/j.apsoil.2011.09.011.

Senesi, S., \& Ghelardi, E. (2010). Production, secretion and biological activity of Bacillus cereus enterotoxins. Toxins, 2( 7 ) , $1690-1703$. D o i : $10.3390 /$ toxins 2071690 .

Setyawan, B., Pawirosoemardjo, S., \& Hadi, H. (2013). Biofungisida Triko Combi sebagai salah satu pengendali jamur akar putih pada tanaman karet. Warta Perkaretan, 32(2), 83-94.

Setyawan, B. (2014). Identifikasi dan uji antagonisme bakteri dari rizosfer Mimosa sp. Terhadap jamur akar putih Rigidoporus microporus strain karet (Tesis), Universitas Gadjah Mada, Indonesia.

Situmorang, A., Suryaningtyas, H., \& Pawirosoemardjo, S. (2007). Current status of white root disease $(R$. microporus) and the disease control management in rubber plantation of Indonesia. Proc. of the Int. Work. White Root Dis. Hevea Rubb. 2006 (p. 27-33). Salatiga, Indonesia: IRRI-IRRDB.

Sujatno., \& Pawirosoemardjo, S. (2001). Pengenalan dan teknik pengendalian penyakit jamur akar putih pada tanaman karet secara terpadu. Warta Perkaretan, 20(1-3), 64-75.

Supriyanto., Priyatmojo, A., \& Arwiyanto, T. (2011). Uji penggabungan PGPF dan Pseudomonas putida strain Pf-20 dalam pengendalian hayati penyakit busuk lunak lidah buaya di tanah gambut. Jurnal Hama dan Penyakit Tumbuhan Tropika, 11(1), 11-21.
Tallent, S. M., Kotewicz, K. M., Strain, E. A., \& Bennett, R. W. (2012). Efficient isolation and identification of Bacillus cereusgroup. Journal of AOAC International, 95(2), 446-451. Doi: 10.5740/jaoacint.11-251

Tan, D., Fu, L., Han, B., Sun, X., Zheng, P., \& Zhang, J. (2015). Identification of an endophytic antifungal bacterial strain isolated from the rubber tree and its application in the biological control of banana fusarium Wilt. PLoS ONE, $10(7), \quad 1-14 . \quad \mathrm{D}$ o $\mathrm{i}$ : 10.1371 /journal.pone.0131974

Ulrich, K., Ulrich, A., \& Ewald, D. (2008). Diversity of endophytic bacterial communities in popular grown under field conditions. FEMS Microbiology Ecology, 63(2), 169-180. Doi: 10.1111/j.1574-6941.2007.00419.x

Yamamoto, S., \& Harayama, S. (1995). PCR amplification and direct sequencing of gyrB genes with universal primers and their application to the detection and taxonomic analysis of Pseudomonas putida Strains. Appl. Environ. Microbiol., 61(3), 1104-1109.

Yin, H., Cao, L., Xie, M., Chen, Q., Qiu, G., Zhou, J., Wu, L., Wang, D., \& Liu, X. (2008). Bacterial diversity based on 16S rRNA and gyrB genes at Yinshan mine, China. Systematic and Applied Microbiology, 31(4), 302-311. Doi: 10.1016/j.syapm.2008.05.003.

Zhao, L., Xu, Y., Sun, R., Deng, Z., Yang, W., $\&$ Wei, G. (2011). Identification and characterization of the endophytic plant growth prompter Bacillus cereus strain MQ23 isolated from Sophora alopecuroides root nodules. Brazilian Journal of Microbiology, 42, 567-575. D o i : 10 . $1590 / \mathrm{S} 1517$. 83822011000200022 . 